\title{
English Language and Literature Students' Perceptions of Critical Thinking
}

\author{
Irfan Tosuncuoglu ${ }^{1}$ \\ ${ }^{1}$ Faculty of Letters, Department of English Language and Literature, Karabuk University, Turkey \\ Correspondence: Irfan Tosuncuoglu, Faculty of Letters, Department of English Language and Literature, Karabuk \\ University, Turkey
}

Received: July 14, 2018

Accepted: August 7, 2018

Online Published: September 10, 2018

doi:10.5430/ijhe.v7n5p20

URL: https://doi.org/10.5430/ijhe.v7n5p20

\begin{abstract}
The fundamental purpose of the function of thinking is to attribute meaning to events in our lives, classify these events into categories and identify them subjectively. As an important dimension of education on thinking, the teaching of critical thinking since the 1950s has attained a wide conceptual framework. Accepted as a factor that facilitates the aquisition and comprehension of information, critical thinking is a desirable learning outcome of education. Some of the characteristics and properties of critical thinking are being aware, systematic, flexible and patient, encompassing open-meaning, metacognition, reconstruction, motivation and discussion. From this point, the perceptions of the students of Karabuk University, English Language and Literature Department, regarding critical thinking, were investigated in detail, in the Spring semester of the academic year 2017-2018. This study is a descriptive one and utilises the survey model to determine the levels of critical thinking in 222 teacher candidates, comprised of students ranging from freshmen to seniors and from both daytime and evening education. The findings have been evaluated and a set of conclusions have been drawn. While a statistical difference according to classes was not found when Anova results were analysed on the sub-dimensions of metacognition, flexibility, systematicity, open-mindedness, a difference was found between the sophomore and senior students on the sub-dimension of perseverance-patience.
\end{abstract}

Keywords: critical thinking, validity, English, teacher

\section{Introduction}

Educational activities in every field prove more and more difficult due to changing human needs (such as employment career and prestige) and after each new piece of knowledge or skill acquired, the need for the learning of a new skill arises. The importance of educational institutions these days has also started to increase progressively due to the persistence of lifelong education. Individuals are inherently thinking beings, yet this does not necessarily make them good thinkers. The difference between thinking and thinking well, is similar to the difference between walking and dancing. While one of them does not arise automatically and requires a certain effort, the other is learned naturally (Gelder 2005; Ritchart \& Perkins 2005).

The skill of thinking is a natural function found in every individual. Presseisen (1985) approaches thinking skills in a progressive manner as "basic processes, problem solving, decision making and creative thinking". That said, thinking itself can sometimes be deficient, prejudiced and insufficient. Fisher (2001), Halpern (2003) and Haskins (2006) suggest that if students are taught how to think, their thinking skills can improve. The way to think depends upon properties such as being conscious and systematic, having flexibility, patience and incorporating open-meaning, metacognition, reconstruction, motivation and discussion (Lee, 1989; Kazanc1, 1989). These properties emphasise that the act of thinking should disentangle itself from prejudices and that it should occur systematically. These properties also verbalise how to think in a critical manner. On the other hand, there exists a powerful and irresistible relationship between the development of formidable and deep language skills with regard to the effective utilisation of English as a foreign language, and the parallel development of an equally formidable critical thinking ability.

\section{Literature Review}

Although there are varying definitions regarding critical thinking, it is widely accepted that it is a high-level cognitive skill which individuals require in order to make accurate and effective decisions throughout their lives. In definitions concerning thinking skills, what draws attention is that problem-solving and decision-making processes are commonly 
mentioned (Seferoğlu \& Akbıyık, 2006). Considered as a factor that facilitates learning, critical thinking is a desired learning outcome of education (Halpern, 1993; Hudgins \& Edelman, 1988).

Along with initiating the development of critical skills between both teachers and students, schools should also undertake the role of encouraging development in critical thinking skills (Malamitsa et al., 2008). When students gain skills in critical thinking, not only will they have control over when and what they think, but also how they think (Osborne et al., 2009). Therefore, thinking skills are improved through asking questions, collecting data and drawing conclusions from related data (Elder and Paul, 2003). In line with this, critical thinking is not only high-level thinking but also a way of seeking knowledge for traditional, social, historical and political roots as well as directing learning into society (Benesch, 1993). It needs to be stated that the success of the student does not merely stem from their having the knowledge of the so called skills such as asking questions, collecting data and critical thinking abilities. Thinking well is based on habits as well as knowledge and attitude. It is necessary to engage in practice in order to learn how to think critically, just as it is in learning a difficult sport. A person who has a great intellect or a very good level of knowledge will not become a good critical thinker merely by virtue of these qualities if he/she does not practice (Allen, 2004; Haskins, 2006; Ritchart and Perkins, 2005). Grant (1988; as cited in Özdemir, 2005) propounds that critical thinking can be generally considered as processes or manner of thinking such as reasoning, high-level thinking, acting wisely and thinking creatively. Beyer (1985) perceives critical thinking as a skill of collecting information, evaluating it and using it effectively. Cüceloğlu (1995) defines critical thinking as "an active and organized mental process in which the aim is to be able to understand ourselves and phenomena around us, by being aware of our own thinking processes and taking others' opinions into account".

Semerci (2016) describes the matter of critical thinking as "a stage involving the examination and evaluation of prejudices, assumptions and every kind of information presented; the discussion of different aspects and conclusions through which a decision is aimed to be made and being able to evaluate how viable the justifications are for the decision". What is obtained from these assumptions, justifications and inferences is put forth at the stage of adequacy. At the stage of establishing communication, the case is that the individual communicates what he/she understands comprehensibly in order to create unanimity and to make a joint decision (Friedel et al., 2008). A series of conceptual tools and strategies related with intellectual skills (Rudinow and Barry, 2007) focused on what to do or what to believe in (Ennis, 1986), comprises critical thinking. According to Ennis (1996) and Lipman (2003; as cited in Topoğlu and Ünal, 2013), decision-making is the primary factor of critical thinking. Reflectiveness and rationality are factors found in prevalent definitions of critical thinking. Similarly, McPeck (1981) has explicated critical thinking as "the education and skill of attempting activity with a reflectivist scepticism".

\section{Critical Thinking: Qualities}

Facione is another researcher who has put forth that the individual who has studied these skills, thinks critically and compels attention through utilising certain skills effectively. According to him, critical thinking skills can be expressed as "interpretation, analysis, evaluation, inference, explanation and self-regulation" (Facione, 1990; Türnüklü-Yeşildere, 2005):

i. Analysis: Defining the relations between the states, questions, concepts, definitions and other factors comprising beliefs, judgements, experiences, knowledge or thoughts.

ii. Interpretation: Expressing the meaning or significance of a state, experience, datum, occurrence, judgement, belief, rule or criterion.

iii. Evaluation: A person's assessment of the states that define his/her perception, experience, belief, judgement or opinion in terms of credibility and reliability.

iv. Inference: Being able to reach rational conclusions, developing healthy projections and hypotheses; taking into account the relevant information in presentations such as data, judgement, state, principle, evidence, belief, opinion, definition, concept and question.

v. Explanation: Putting forth the conclusions drawn from reasoning, judging this reasoning with proof and criteria in conceptual, methodological, contextual dimensions and expressing it with convincing evidence.

Facione (2007) also denotes the criteria of an ideal critical thinker according to the Delphi Report consensus as inquisitive, well informed, trustful of reason, open minded, flexible, and fair minded in evaluation, willing to reconsider, diligent in seeking relevant information. Critical thinking is also awareness of one's own thinking and reflection on the thinking of the self and others as an object of cognition" (Kuhn \& Dean, 2004; cited in Semerci \& Elald1, 2014). Therefore, critical thinking is related to the development of metacognitive understanding which is essential to lead to high levels of cognition (Lockwood, 2003). 
The aforementioned properties express individuals' knowledge of themselves and their talents, as well as their ability to receive opinions from others without prejudice, and to revise and change their own opinions when necessary. Besides, they emphasise the affective attributes such as curiosity, flexibility, self-confidence and impartiality along with intellectual skills. Another compulsory condition of being a good critical thinker is to practice. The necessity to use intellectual skills in conjunction with effective ones, exhibits the difference between the teacher and the environment to be created in teaching critical thinking in a conventional classroom. First and foremost, the environment created should be secure as to allow the students to express themselves comfortably. Strategies such as asking questions, collaborative working, utilising knowledge, creating sensitivity and versatile perspective (Berman, 1991; Haskins, 2006) should be taken into consideraton. However, situations that hinder the establishment of such an environment are the inability to think independently, over-confidence in logic, hardheadedness and stubbornness, complacency, perfectionism, exhibition of dogmatic behaviour, acting impulsively, over-confidence in relation to the teacher and lack of self-confidence (Clark \& Starr, 1991; Fisher, 2001; Halpern, 2003; Haskins, 2006). Teachers who aim to develop critical thinking in their students should remove the obstacles arising from different factors and improve their thinking. In order to do this, an assessment should be made and the disposition of the students in respect to critical thinking should be measured. In this study, a scale to measure this disposition towards critical thinking has been planned .

\section{Method}

This is a descriptive study, orientated towards analysing the critical thinking disposition of teacher candidates. The survey method has been used with the aim of determining the present levels of the critical thinking disposition of teacher candidates receiving education in the Karabük University English Language and Literature Department. With this model, events and objects are described in their present situation (Sönmez \& Alacapınar, 2011; Karasar, 1995). In the study, the "Critical Thinking Disposition (CTD)" scale has been utilised and consists of forty-nine items, put forth by Semerci (2000) and further developed by Semerci (2016). The validity and reliability of the CTD scale has been ensured and its confirmatory factor analysis has been performed through AMOS software (Kay square=2778.981, $\mathrm{Sd}=1073, \mathrm{X}^{2} / \mathrm{Sd}=2.590, \mathrm{GFI}=0.903, \mathrm{CFI}=0.932$, RMSEA=0.038), and according to these results, the applicability of the scale to teachers and teacher candidates has been expressed by Semerci (2016).

\section{Population and Study Sample}

The population of the study is comprised of 222 students out of 500 studying at Karabük University Faculty of Literature in the English Language and Literature Department during the Spring semester of 2017-2018. The study was sampled in a standard way. In this type of research, the sample is randomly ascertained from a pre-determined list. In addition, the point to consider here is that the factors in the list created, consist of similar features such as age, level, etc., (Çepni, 2007). The survey related to critical thinking consisted of forty-nine items was applied to the students receiving education in the English Language and Literature Department at Karabük University and the results were evaluated.

The experiment was applied to 222 students, $149(67.1 \%)$ of whom were female students and 73 (32.9\%) of whom are male students.

Table 1.

\begin{tabular}{lc}
\hline Gender & Number of the students \\
\hline Female & 149 \\
Male & $\mathbf{7 3}$
\end{tabular}

In addition to this, $112(50 . \overline{5 \%})$ of students were selected from daytime attendance while $110(49.5 \%)$ of them were selected from evening attendance. The university entrance exam scores of the students receiving evening education are slightly lower than the students receiving education during the day.

Table 2.

\begin{tabular}{lc}
\hline Education Type & Number of the students \\
\hline I.Daytime Education & 112 \\
II. Evening Education & $\mathbf{1 1 0}$
\end{tabular}

Additionally, 79 (35.6\%) of students who participated in the experiment are freshmen, 95 (42.8\%) are sophomores, $23(10.4 \%)$ are juniors and $25(11.3 \%)$ are seniors. 
Table 3.

\begin{tabular}{ll}
\hline Courses & Number of students \\
\hline $1^{\text {st }}$ & 79 \\
$2^{\text {nd }}$ & 95 \\
$3^{\text {rd }}$ & 23 \\
$\mathbf{4}^{\text {th }}$ & $\mathbf{2 5}$ \\
\hline
\end{tabular}

\section{Results}

The t-test was applied in the experiments. This is known to compare two averages (means) and highlight the differences.

Table 4. t-test results regarding critical thinking according to gender

\begin{tabular}{|c|c|c|c|c|c|c|}
\hline Variable & $\mathrm{N}$ & $\mathrm{X}$ & $S$ & SD & $\mathrm{t}$ & $\mathrm{P}$ \\
\hline \multicolumn{7}{|c|}{ Metacognition } \\
\hline Female & 149 & 3.91 & 0.47 & 219 & 1.252 & 0.212 \\
\hline Male & 72 & 3.81 & 0.67 & & & \\
\hline \multicolumn{7}{|c|}{ Flexibility } \\
\hline Female & 149 & 3.88 & 0.50 & 219 & 0.005 & 0.996 \\
\hline Male & 72 & 3.88 & 0.80 & & & \\
\hline \multicolumn{7}{|c|}{ Systematicity } \\
\hline Female & 149 & 3.70 & 0.58 & 219 & 0.720 & 0.472 \\
\hline Male & 72 & 3.63 & 0.64 & & & \\
\hline \multicolumn{7}{|c|}{ Perseverance-patience } \\
\hline Female & 149 & 3.63 & 0.74 & 219 & 0.534 & 0.594 \\
\hline Male & 72 & 3.57 & 0.72 & & & \\
\hline \multicolumn{7}{|c|}{ Open-mindedness } \\
\hline Female & 149 & 3.86 & 0.72 & 219 & $(0.580)$ & 0.562 \\
\hline Male & 72 & 3.98 & 2.14 & & & \\
\hline
\end{tabular}

When the test result regarding critical thinking according to the variable of gender is analysed, it was seen that there is no statistical difference between the sub-dimensions of metacognition $(\mathrm{t}=1.252, \mathrm{p}>0.05)$, flexibility ( $\mathrm{t}=0.005$, $\mathrm{p}>0.05)$, systematicity $(\mathrm{t}=0.720, \mathrm{p}>0.05)$, perseverance-patience $(\mathrm{t}=0.534, \mathrm{p}>0.05)$, open-mindedness $(\mathrm{t}=-0.580$, $\mathrm{p}>0.05)$. 
Table 5. T-test results according to groups (Daytime Education-1, Evening Education-2)

\begin{tabular}{|c|c|c|c|c|c|c|}
\hline Variable & $\mathrm{N}$ & $\mathrm{X}$ & $\mathrm{S}$ & $\mathrm{sd}$ & $\mathrm{t}$ & $\mathrm{P}$ \\
\hline \multicolumn{7}{|c|}{ Metacognition } \\
\hline 1 & 112 & 3.90 & 0.47 & 220 & 0.563 & 0.574 \\
\hline 2 & 110 & 3.86 & 0.60 & & & \\
\hline \multicolumn{7}{|l|}{ Flexibility } \\
\hline 1 & 112 & 3.88 & 0.51 & 220 & 0.205 & 0.837 \\
\hline 2 & 110 & 3.87 & 0.70 & & & \\
\hline \multicolumn{7}{|c|}{ Systematicity } \\
\hline 1 & 112 & 3.71 & 0.61 & 220 & 0.808 & 0.420 \\
\hline 2 & 110 & 3.64 & 0.58 & & & \\
\hline \multicolumn{7}{|c|}{ Perseverance-patience } \\
\hline 1 & 112 & 3.57 & 0.74 & 220 & $(0.776)$ & 0.439 \\
\hline 2 & 110 & 3.65 & 0.72 & & & \\
\hline \multicolumn{7}{|c|}{ Open-mindedness } \\
\hline 1 & 112 & 3.88 & 0.79 & 220 & $(0.237)$ & 0.813 \\
\hline 2 & 110 & 3.92 & 1.75 & & & \\
\hline
\end{tabular}

When the test result regarding critical thinking according to groups was analysed, it showed no statistical difference between the sub-dimensions of metacognition $(\mathrm{t}=0.563, \mathrm{p}>0.05)$, flexibility $(\mathrm{t}=0.205, \mathrm{p}>0.05)$, systematicity $(\mathrm{t}=0.808$, $\mathrm{p}>0.05)$, perseverance-patience $(\mathrm{t}=-0.776, \mathrm{p}>0.05)$ and open-mindedness $(\mathrm{t}=-0.237, \mathrm{p}>0.05)$. 
Table 5. The mean and standard deviation results of the sub-dimensions of critical thinking according to courses.

\begin{tabular}{|c|c|c|c|}
\hline & $\mathrm{N}$ & $\mathrm{X}$ & $\mathrm{S}$ \\
\hline \multicolumn{4}{|c|}{ Metacognition } \\
\hline 1 & 79 & 3.91 & 0.66 \\
\hline 2 & 95 & 3.80 & 0.46 \\
\hline 3 & 23 & 3.88 & 0.40 \\
\hline 4 & 25 & 4.10 & 0.54 \\
\hline Total & 222 & 3.9 & 0.55 \\
\hline \multicolumn{4}{|c|}{ Flexibility } \\
\hline 1 & 79 & 3.92 & 0.57 \\
\hline 2 & 95 & 3.80 & 0.69 \\
\hline 3 & 23 & 3.91 & 0.41 \\
\hline 4 & 25 & 3.99 & 0.58 \\
\hline Total & 222 & 3.88 & 0.61 \\
\hline \multicolumn{4}{|c|}{ Systematicity } \\
\hline 1 & 79 & 3.70 & 0.66 \\
\hline 2 & 95 & 3.62 & 0.53 \\
\hline 3 & 23 & 3.61 & 0.43 \\
\hline 4 & 25 & 3.88 & 0.61 \\
\hline Total & 222 & 3.68 & 0.60 \\
\hline \multicolumn{4}{|c|}{ Perseverance-patience } \\
\hline 1 & 79 & 3.63 & 0.75 \\
\hline 2 & 95 & 3.53 & 0.66 \\
\hline 3 & 23 & 3.47 & 0.75 \\
\hline 4 & 25 & 4.00 & 0.83 \\
\hline Total & 222 & 3.61 & 0.73 \\
\hline \multicolumn{4}{|c|}{ Open-mindedness } \\
\hline 1 & 79 & 3.87 & 0.82 \\
\hline 2 & 95 & 3.89 & 1.87 \\
\hline 3 & 23 & 3.81 & 0.74 \\
\hline 4 & 25 & 4.17 & 0.70 \\
\hline Total & 222 & 3.90 & 1.36 \\
\hline
\end{tabular}

When the mean and standard deviation results of the sub-dimensions of critical thinking according to classes were analysed, it was seen that students focused on the "Mostly Agree (4)" option on the sub-dimensions of metacognition, flexibility, systematicity, perseverance and patience, and open-mindedness. The highest mean was seen in open-mindedness in senior-year students while the lowest mean was seen in perseverance-patience in junior-year students. 
Table 6. ANOVA results of the sub-dimensions of critical thinking according to classes

\begin{tabular}{|c|c|c|c|c|c|}
\hline & $\begin{array}{l}\text { Sum } \\
\text { of squares }\end{array}$ & $\mathrm{Sd}$ & $\begin{array}{l}\text { Mean } \\
\text { of squares }\end{array}$ & $\mathrm{F}$ & $\mathrm{P}$ \\
\hline \multicolumn{6}{|c|}{ Metacognition } \\
\hline Intergroups & 1.858 & 3 & 0.619 & 2.103 & 0.101 \\
\hline Intragroups & 64.220 & 218 & 0.295 & & \\
\hline sum & 66.079 & 221 & & & \\
\hline \multicolumn{6}{|l|}{ Flexibility } \\
\hline Intergroups & 0.988 & 3 & 0.329 & 0.828 & 0.453 \\
\hline Intragroups & 81.794 & 218 & 0.375 & & \\
\hline sum & 82.782 & 221 & & & \\
\hline \multicolumn{6}{|c|}{ Systematicity } \\
\hline Intergroups & 1.328 & 3 & 0.443 & 1.223 & 0.302 \\
\hline Intragroups & 78.871 & 218 & 0.362 & & \\
\hline sum & 80.198 & 221 & & & \\
\hline \multicolumn{6}{|c|}{ Perseverance-patience } \\
\hline Intergroups & 5.011 & 3 & 1.670 & 3.203 & 0.024 (2 to 4$)$ \\
\hline Intragroups & 113.680 & 218 & 0.521 & & \\
\hline sum & 118.691 & 221 & & & \\
\hline \multicolumn{6}{|c|}{ Open-mindedness } \\
\hline Intergroups & 2.130 & 3 & 0.710 & 0.382 & 0.766 \\
\hline Intragroups & 404.883 & 218 & 1.857 & & \\
\hline sum & 407.014 & 221 & & & \\
\hline
\end{tabular}

While a statistical difference according to classes has not been found when ANOVA results have been analysed on the sub-dimensions of metacognition $(\mathrm{F}=2.103, \mathrm{P}>0.05)$, flexibility $(\mathrm{F}=0.8287, \mathrm{P}>0.05)$, systematicity $(\mathrm{F}=1.223$, $\mathrm{P}>0.05)$, open-mindedness $(\mathrm{F}=0.382, \mathrm{P}>0.05)$, a difference has been found between the sophomore and senior students on the sub-dimension of perseverance-patience $(\mathrm{F}=2.103, \mathrm{P}>0.05)$.

\section{Conclusion and Discussion}

Critical thinking is a desired objective of current educational programmes. However, individuals who can effectively utilise critical thinking in their lives are individuals who possess the skills and disposition necessary for critical thinking. 222 students receiving education in the English Language and Literature Department at Karabük University participated in the study orientated towards measuring their perceptions of subdimensions regarding critical thinking. The aim was to ascertain the perception of students with regard to critical thought from the scale developed by Semerci (2016) which consists of forty-nine items the reliability of which is quite high has been applied and the data analysed. According to this;

When the test results regarding critical thinking according to the variable of gender were examined in order to understand the importance of gender factor, it was seen that there is no statistical difference according to gender between the sub-dimensions of metacognition, flexibility, systematicity, perseverance-patience and open-mindedness. 
When the test result regarding critical thinking according to groups (Daytime education, Evening education) was analysed, it was seen that there is no statistical difference between the sub-dimensions of metacognition, flexibility, systematicity, perseverance-patience and open-mindedness.

When the mean and standard deviation results of the sub-dimensions of critical thinking according to classes were analysed, students focused on the "Mostly Agree (4)" option on the sub-dimensions of metacognition, flexibility, systematicity, perseverance and patience, and open-mindedness. The highest mean was seen in open-mindedness in senior-year students while the lowest mean was seen in perseverance-patience in junior-year students. While a statistical difference according to classes was not found when Anova results were analysed on the sub-dimensions of metacognition, flexibility, systematicity, open-mindedness, a difference was found between the sophomore and senior students on the sub-dimension of perseverance-patience.

It is seen that senior-year students have more perseverance and patience in comparison to sophomore-year students in the sub-dimension of perseverance-patience. That is to say, as the class level gets higher, the students gain more perseverance and patience in general. This result is in line with the ideas by Lee (1989) and Kazanc1 (1989) which support the theory that the way to think depends upon properties such as being conscious and systematic, flexible, patient, open-meaning and receptive to metacognition, reconstruction, motivation and discussion.

In conclusion, it can be said that critical thinking is an important cognitive skill which affects students' viewpoints on events, their perceptions concerning what transpires in their environment and their decision-making processes. The instillment of critical thinking skills and its application should be among the objectives of contemporary education programmes and should occupy the fundamental position in the learning of thinking skills. In addition to this, the responsibility to create more effective critical thinking environments in classrooms, falls to a great extent on the shoulders of teachers and instuctors.

\section{References}

Allen, M. (2004). Smart Thinking Skills for Critical Understanding and Writing. Oxford: Oxford University Press.

Benesch, S. (1993). Critical thinking: A Learning Process for Democracy. TESOL Quarterly, 27, 545-547. https://doi.org/10.2307/3587485

Berman, S. (1991). Thinking in Context: Teaching for Open-mindedness and Critical Understanding, Developing Minds. Edited by Arthur L. Costa: USA.

Beyer, B. K. (1988). DeveIoping a scope and sequence for thinking skills instruction. Educational Leadership, 7 , 26-30.

Clark, L.H., \& Starr (1991). Secondary and Middle School Teaching Methods. Newyork: Macmillan Publishing Company.

Cüceloğlu, D. (1995). İyi Düsün Dogru Karar Ver. İstanbul: Sistem Yayıncılık.

Elder, L., \& Paul, R. (2003). Critical thinking: Strategies for improving student learning, part III. Journal of Developmental Education, 40.

Ennis, R. H. (1986). A Taxonomy of Critical Thinking Dispositions and Abilities. Teaching Thinking Skills Theory and Practice (Edited by: Robert J. Sternberg). New York: W.H. Freeman and Company.

Ennis, R. H. (1996). Critical Thinking. Upper Saddle River, NJ: Prentice Hall.

Facione, P. (1990). Critical thinking: A statement of expert consensus for purposes of educational assessment and instruction (Executive Summary). American Philosophical Association (ERIC Document Reproduction Service No. ED315 423).

Facione, P. (2007). Critical thinking: What It is and why it counts. Insight assessment. The California Academic Press, Millbrae, CA.

Fisher, A. (2001). Critical Thinking: An Introduction. Cambridge: Cambridge University Press.

Friedel, C., Irani, T., Rudd, R., Gallo, M.; Eckhardt, E. \& Ricketts, J. (2008). Overtly teaching critical thinking and inquiry- based learning: A comparison of two undergraduate biotechnology classes. Journal of Agricultural Education, 49(1), 72- 84. https://doi.org/10.5032/jae.2008.01072

Gelder, T. V. (2005). Teaching Critical learning: Some Lessons from Cognitive Science. College Teaching, 45(1), 1-6. https://doi.org/10.3200/CTCH.53.1.41-48

Grant, G. E. (1988). Teaching Critical Thinking. New York: Praeger Publishers. 
Halpern, D. F. (1993). Assessing the Effectiveness of Critical-Thinking Instruction. The Journal of General Education, 42(4), 338-353.

Halpern, D. F. (2003). Thoughts and Knowledge: An Introduction to Critical Thinking. New Jersey-London: Lawrence Erlbaum Associates.

Haskins, G. R. (2006). A Practical Guide to Critical Thinking. Retrieved, 17.02.2018, from http://skepdic.com/essays/haskins.pdf.

Hudgins, B. B., \& Edelman, S. (1988) Children's Self-Directed Critical Thinking. Journal of Educational Research, May/June, 81(5), 262-273. https://doi.org/10.1080/00220671.1988.10885834

Karasar, N. (1995). Bilimsel Araştırma Yöntemi. 7. Basım, Ankara: Alkım Yayınevi.

Kazanc1, O. (1989). Ĕgitimde Eleştirici Düşünme ve Öğretimi. Ankara: Kazancı Kitap Ticaret A.Ş.

Kuhn, D., \& Dean, D. (2004). Metacognition: A bridge between cognitive psychology and educational practice. Theory into Practice, 43(4), 268-273. https://doi.org/10.1207/s15430421tip4304_4

Lee, H.D. (1989). Workshop Conducted for Wisconsin State Board of Vocational, Technical and Adult Education (Final Raport). University of Wisconsin-Stout Menomonie, WI 54751: Center for Vocational, Technical and Adult Education.

Lipman, M. (2003). Thinking in Education. Cambridge: Cambridge University. https://doi.org/10.1017/CBO9780511840272

Lockwood, F. (2003). Metacognition and critical thinking for effective learning. Retrieved, May 30, 2018, from http://members.shaw.ca/donlockwood/critical.htm.

Malamitsa, K., Kokkotas, P., Kasoutas, M. (2008). Graph / Chart interpretation and reading comprehension as critical thinking skills. Science Education International, 19(4), 371-384.

Mcpeck, J. (1981). Critical Thinking and Education. New York: St. Martin's Press.

Osborne, R. E., Kriese P., Tobey, H., \& Johnson, E. (2009). Putting it all together: Incorporating SoTL practices for teaching interpersonal and critical thinking skills in an online course. A Journal of Scholarly Teaching, 4, 4552.

Özdemir, S. M. (2005). Üniversite Öğrencilerinin Eleştirel Düşünme Becerilerinin Çeşitli Değişkenler Açısından Değerlendirilmesi. Gazi Üniversitesi Eğitim Fakültesi Dergisi, 3(3), 297- 316.

Presseisen, B. Z. (1985). Thinking skills: Meanings, models, materials. A. Costa (Ed.), Developing Minds (p. 43-48). Alexandria, VA: Association for Supervision and Curriculum Development.

Ritchart, R., \& Perkins, D. N. (2005). Learning to Think: The Challenges of Teaching Thinking. The Cambridge Handbook of Thinking and Reasoning. (ed: Keith J. Holyoak ve Robert G. Morrison), Cambridge: Cambridge University Press, ss. 775-802.

Rudinow, J., \& Barry, V. E. ( 2007). Invitation to Critical Thinking. 6th ed. Belmont, CA: Thomson Wadsworth.

Seferoğlu, S. S., \& Akbıyı, C. (2006). Eleştirel Düşünme ve Öğretimi. H.Ü. Eğitim Fakültesi Dergisi, (H.U. Journal of Education), 30, 193- 200.

Semerci, Ç., \& Elaldı, Ş.(2014). The Roles of Metacognitive Beliefs in Developing Critical Thinking Skills. Bartın University Journal of Faculty of Education, 3(2), 317-333. DOI:10.14686/BUEFAD. 201428187

Semerci, N. (2000). Kritik Düşünme Ölçeği. Eğitim ve Bilim, 25(116), 23-26.

Semerci, N. (2016). Eleştirel Düşünme Eğilimi (EDE) Ölçeğinin Geliştirilmesi: Geçerlik ve Güvenirlik Revize Çalışması. Turkish Studies International Periodical for the Languages, Literature and History of Turkish or Turkic, 11(9), 725-740,. DOI Number: http://dx.doi.org/10.7827/Turkish Studies.

Sönmez, V., \& Alacapınar, F.G. (2011). Örneklendirilmiş bilimsel araştırma yöntemleri. Ankara: ANI Yayıncılık.

Topoğlu, O., \& Ünal, Ö.E. (2013). Eğitim fakültesi güzel sanatlar eğitimi bölümü öğrencilerinin eleştirel düşünme eğilimlerinin çeşitli değişkenlerle ilişkisinin incelenmesi. Turkish Studies - International Periodical for the Languages, Literature and History of Turkish or Turkic, 8(8), 1301-1312.

Türnüklü, E. B., \& Yeşildere, S.(2005). Problem, Problem Çözme Ve Eleştirel Düşünme. Gazi Eğitim Fakültesi Dergisi, 25(3), 107-123. 